\title{
PEDAGOGICAL APPROACHES TO PROBLEM SOLVING IN HIGHER EDUCATION
}

\author{
Anna Vintere \\ Latvia University of Life Sciences and Technologies, Latvia \\ Anna.Vintere@llu.lv
}

\begin{abstract}
One of the most often mentioned competence in the surveyed literature is problem solving. It is also one of the key skills for the sustainable development of society. The article includes analysis of pedagogical approaches like project-based, problem-based learning and enquiry-based learning, as well as describes the use of design thinking as one of the problem solving approaches in higher education. As mathematics studies at universities play an important role in developing problem solving skills, an empirical study was carried out to identify the pedagogical approaches used by mathematics teachers and to illustrate the development of problem solving skills in mathematics studies at universities in Latvia. It includes a survey of mathematics teachers in Latvia aimed at identifying their experience in implementing different pedagogical approaches to mathematics and assessing the extent to which these methods help develop problem solving skills. The answers of mathematics teachers show that problem solving skills are developed at the middle level, which means only for the use in a certain situation (that is slightly different from previously known). The most effective approach to promoting problem-solving skills is the so-called context approach, which means focusing on the practical task related to a specialty. In the empirical study self-assessment method is used and the results are based only on respondents' opinion.
\end{abstract}

Key words: case study, design thinking, pedagogical approaches, problem-solving skills, survey.

\section{Introduction}

The scientific literature contains a number of studies on knowledge, skills and competences as key elements of sustainable development. The concept of competence is seen as an essential guide to orientate teaching and learning to sustainable public development. The European Commission (EC) documents also deal with the issue of competence by identifying different key competences, each of which contributes to a successful life in society (EC, 2006, 2018). Key competences include skills such as critical thinking, problem solving, teamwork, communication and negotiation skills, analytical skills, creativity and intercultural skills (EC, 2018).

One of the most frequently above-mentioned competencies in literature is problem solving. In the World Economic Forum (2016), this skill was identified as one of the ten skills needed for future employment (World Economic Forum, 2016). Also, a study conducted by employers in the United States highlighted problem-solving skills and critical thinking as some of the important skills needed by young people entering the labour market (The Conference Board, 2006).

At the World Economic Forum in 2018, it was noted that 'skills continuing to grow in prominence by 2022 include analytical thinking and innovation, as well as active learning and learning strategies. ... 'human' skills such as creativity, originality and initiative, critical thinking, persuasion, and negotiation will likewise retain or increase their value, as will attention to detail, resilience, flexibility and complex problem-solving' (World Economic Forum, 2018). This document also emphasizes the importance of problem-solving skills both in the economy as a whole and in jobs that require flexibility and innovation.
Higher education has to fulfil requirements of modern trends in the development of society. For that reason, the aim of university study programs is to develop analytical ability and skills, and provide students with the knowledge and skills necessary to be work-ready and competitive specialists in the labour market. According to the European Qualifications Framework (EQF), the results of studies is 'advanced knowledge of a field of work or study, involving a critical understanding of theories and principles; advanced skills, demonstrating mastery and innovation, required to solve complex and unpredictable problems in a specialised field of work or study' (Descriptors defining..., 2016). For this reason, the aim of this study is to identify pedagogical approaches to foster problem-solving skills during university studies, as well as to carry out comparative analysis of the identified approaches.

Mathematics is one of the disciplines that develops problem-solving skills. When problems arise in mathematics and other contexts, students should apply and adapt various appropriate strategies to solve problems, monitor and analyse the problems of mathematical processes (Zeidmane \& Rubina, 2018). According to Serve (1957), mathematics develops logical thinking that includes the ability to think deductively, ability to abstract, generalize, classify, ability to think, analyse, criticize. For this reason, an empirical study was carried out to identify the pedagogical approaches used by mathematics teachers and to illustrate the development of problem solving skills in mathematics studies at universities in Latvia.

\section{Materials and Methods}

The study includes two parts. The first part of this paper is the result of scientific analysis and 
assessment of scientific literature as well as a number of information sources taking into consideration the author's reflection of experience and observations in connection with approaches allowing the development of university students' problem-solving skills.

Problem-solving skills here are understood as 'goal-directed thinking and action in situations for which no routine solution procedure is available. The problem solver has a more or less well-defined goal, but does not immediately know how to reach it. The incongruence of goals and admissible operators constitutes a problem. The understanding of the problem situation and its step-by-step transformation, based on planning and reasoning, constitute the process of problem solving' (Finegold \& Notabartolo, 2016). The scientific literature shows that students need to develop different skills, including problem solving using holistic and systemic approaches, making critical judgements on real life issues, applying theory to practice and vice versa, and working collaboratively and in interdisciplinary teams (Parkin et al., 2004; Dawe, 2005).

The aim of the empirical part of the research is to illustrate the use of pedagogical approaches in higher education. In the framework of this study, a case study has been conducted. It was based on a survey of mathematics teachers in Latvia, aimed at identifying their experience in implementing different pedagogical approaches in mathematics and assessing the extent to which these methods help develop problem solving skills.

In the survey the participants were asked to evaluate their mathematics study course on the scale from 0 to 3 , which contributes to lower problem solving skills, where:

a) 3 - can be used in different life situations and in a new context,

b) 2 - can be used in a particular situation that is somewhat different from previously known,

c) 1 - developed only at reproductive level,

d) 0 - this competence is not required for students of this specialty.

Teachers were also asked to indicate which of the given teaching methods (project based, problembased, enquiry-based) they use and to rank them by priority numbering $1,2,3, \ldots$, as well as open question - to indicate one method that they find the most effective in promoting the development of the problem solving skills.

The empirical study was conducted in late 2018 . The sample of this study - 56 mathematics teachers from different universities in Latvia, but only 12 questionnaires, which have been taken as the basis for this study, were completely filled. It should, therefore, be noted that this was a case study, and the study uses the self-assessment method. The questionnaire (in
Latvian) is available at: http://www.iipc.lv/surv/index. php/survey/index/sid/895516/newtest/Y/lang/en.

\section{Results and Discussion}

One of the most often mentioned competences in the surveyed literature is problem solving. It is also one of the key skills for the sustainable development of society. Different methods and pedagogical approaches are discussed in the scientific literature as the effective development of problem solving skills. The author has selected four of the most common approaches to developing problem solving skills: problem-based, project-based and inquiry learning, as well as design thinking.

'Problem-based learning emphasizes learning by doing. It also provides a motivating context for learning. Students are given a real-world problem similar to those they face as professionals' (Steinemann, 2003). The benefits of problem-based learning are the development of professional skills, independence and cooperation, the activation of learning through a variety of resources, solving a complex problem, etc.

The second most often mentioned approach is project-based learning. According to Helle (2006), the main feature of project-based learning is that the problem itself serves to organize and manage student activities, and these activities end with the final product. Project-based learning includes different activities (Helle, 2006):

1) the solution of the problem, set by a student himself,

2) initiative by a student group and a variety of educational activities,

3) commonly results in an end product (e.g., thesis, report, design plans, computer program and model,

4) 'work goes on for a considerable length of time',

5) teachers involved as advisors.

Inquiry-based learning is one of the approaches of constructivist theory. Inquiry learning is a social process in which individuals learn through collaboration with others, continue to acquire new knowledge and understanding based on existing experience, choosing and transforming information.

Design thinking is a relatively new pedagogical approach. Although there are many examples in the scientific literature that characterize this approach as an effective learning strategy, in Latvia it is not yet sufficiently integrated in the education process. The design thinking focuses on creative problem solving, innovation and also practical skills, as well as the ability to see the link between the things we know. The more we know, the more interconnection we can create (Krūmiņa, 2018).

Design thinking involves changing attitudes towards traditional things by combining analytical and creative 


\section{Comparative analysis of pedagogical approaches}

\begin{tabular}{|l|l|}
\hline \multicolumn{1}{|c|}{ Pedagogical approach } & \multicolumn{1}{c|}{ Approach characteristics } \\
\hline Project-based learning & $\begin{array}{l}\text { Approach includes a measure or activity that has a specific purpose and result, and is } \\
\text { implemented over a specified period of time (with certain resources) }\end{array}$ \\
\hline Problem-based learning & $\begin{array}{l}\text { The goal of the approach is to find a solution to the problem. This is usually done by the } \\
\text { so-called 'three-step technique: problem analysis, solution search, idea evaluation and } \\
\text { implementation }\end{array}$ \\
\hline Inquiry learning & $\begin{array}{l}\text { Not so much attention is paid to solving the problem as to the issues that arise from this } \\
\text { problem }\end{array}$ \\
\hline Design thinking & $\begin{array}{l}\text { A new, innovative approach focused on solving the problem and creating the desired } \\
\text { outcome, focused on the human being, his needs and desires }\end{array}$ \\
\hline
\end{tabular}

thinking, making manageable and understandable creation of a wide range of innovations, and contains case and event studies, idea creation, solution development, and thinking management techniques in a specific order to achieve problem solving with maximum efficiency (Razzouk \& Shute, 2012).

'The Design thinking process begins with a problem finding process that engages with the world around to discover needs and insights that might drive the innovation of products, services or systems of various scales and complexities' (Melles et al., 2015).

Several studies show that the use of design thinking is also effective in education, especially in social and business studies (Matthews \& Wrigley, 2017). The method is successfully used for the development of the so- called soft skills: communication, negotiation, understanding of the needs of other people, working in teams, decision making etc. By participating in the Baltic University program, the author has also become familiar with the use of this method for curriculum development and improvement of the educational process, successfully implemented by Kaunas University of Technology.

Table 1 gives the comparative analysis of pedagogical approaches depending on the nature of the approach and the contribution to the problem.

The results of the empirical study showed that the average rating of the development of problem solving skills in the mathematics study course is 1.5 , but median and mode -2 on a three-point scale.

Of the proposed teaching methods, the lead is a lecture, which has been marked as the first priority by 9 mathematics teachers surveyed, but as the second priority - by 3 . In mathematics studies, project-based learning is not popular because it is mentioned only once, in addition as a third priority.

The respondents were asked to indicate whether the mathematics course they led was using the pedagogical approaches given in the questionnaire. In turn, the answer 'yes' and 'no' to the questions about the use of the problem-based and inquiry-based learning approaches were distributed evenly -6 to 6 .

The questionnaire also included an open question where teachers had to write one learning method which they thought was most effective in promoting problem-solving skills. The most frequently mentioned answer was the creation and solving of practical tasks. Here, with practical tasks, are understood the tasks in connection with specialty and also the real-world situations. Problem-based learning highlighted the importance of working on complex, real problems that students experience in developing knowledge, skills and competences, which is an important part of problem-based learning (Lozano et al., 2017).

Three other pedagogical approaches are often mentioned: project work, work in groups and case studies. As mentioned above, the project work and project-based learning are not often used in mathematics teaching. Case studies are also not often used. This method is mentioned only twice as a method used in mathematics studies, with the fourth and seventh priority. The results of the survey showed that work in groups is used by a quarter of the surveyed teachers, giving it the fourth or fifth priority.

\section{Conclusions}

1. There are four approaches to problem solving skills: project-based (result-oriented), inquiry learning (focused on identification of questions related to the problem), problem-based (finding the solution of the problem), and design thinking (search for new alternatives rather than choosing from existing ones where the decision is empathetic to the person).

2. The results of the empirical study show that the average rating of the development of problem solving skills in the mathematics study course is 1.5 , but median and mode -2 on a threepoint scale. Case studies and project work in mathematics studies are rarely used. The most 
effective approach in promoting problem-solving skills is the so-called contextual approach, which means focusing on the solving of practical tasks.

3. The empirical part of the research uses a selfassessment method, therefore the results are based on the respondents' opinion. It was a case study and it only reflected the views of the teachers involved. So the results cannot be generalized. The study identified problems / directions for an in-depth research.

\section{Acknowledgements}

The paper was supported by the grant from LLU program 'Strengthening the Scientific Capacity in the LLU' no. Z32 called 'Development of the didactical model for transforming mathematics studies into education for sustainable development'.

\section{References}

1. Dawe, G., Jucker, R., \& Martin, S. (2005). Sustainable development in higher education: Current practice and future developments. A report for the Higher Education Academy: York.

2. Descriptors defining levels in the European Qualifications Framework. (2016). EU: Learning Opportunities and Qualifications in Europe. Retrieved March 1, 2019, from https://ec.europa.eu/ploteus/en/content/ descriptors-page.

3. EC. (2006). Recommendation of the European Parliament and of the Council of 18 December 2006 on key competences for lifelong learning (2006/962/EC). Official Journal of the European Union, L394, 30 December 2006, pp. 10-18. Retrieved February 28, 2019, from http://eur-lex.europa.eu/legal-content/EN/ TXT/?uri=celex:32006H0962.

4. EC. (2018). Annex to Proposal for a Council Recommendations on Key Competences for LifelongLearning. A European Framework (2018) Retrieved February 28, 2019, from https://eur-lex.europa. eu/resource.html?uri=cellar:395443f6-fb6d-11e7-b8f5-1aa75ed71a1.0001.02/DOC_2\&format=PDF.

5. Finegold, D., \& Notabartolo, A.S. (2016). $21^{\text {st }}$-Century Competencies and Their Impact: An Interdisciplinary Literature Review. Executive Summary. Retrieved March 2, 2019, from https:/hewlett.org/wp-content/ uploads/2016/11/21st_Century_Competencies_Impact.pdf.

6. Helle, L. (2006). Project based learning in post-secondary education - theory, practice and robber sling shots. Higher education. Volume 51, pp. 25-56.

7. Krūmiņa, A.A. (2018). Dizaina domāšana pedagoğijas kontekstā (Design Thinking in the Context of Pedagogy). Society. Integration. Education. Proceedings of the International Scientific Conference. Vol. IV, 25-26 May 2018, 423-434. (in Latvian)

8. Lozano, R., Merrill, M.Y., Sammalisto, K., Ceulemans, K., \& Lozano, F.J. (2017). Connecting Competences and Pedagogical Approaches for Sustainable Development in Higher Education: A Literature Review and Framework Proposal. Sustainability, 2017, 9, 1889. Retrieved February 10, 2019, from www.mdpi.com/ journal/sustainability.

9. Matthews, J., \& Wrigley, C. (2017). Design and Design Thinking in Business and Management Higher Education. Retrieved February 25, 2019, from https://www.jld.edu.au/article/view/294.html.

10. Melles, G., Anderson, N., Barrett, T., \& Thompson-Whiteside S. (2015). Problem Finding through Design Thinking in Education. In book: Inquiry-based Learning, Chapter: 11, Publisher: Emerald Publishing, Editors: Patrick Blessinger, pp. 189-208. DOI: 10.1108/S2055-364120150000003027.

11. Parkin, S., Johnson, A., Buckland, H., \& White, E. (2004). Learning and Skills for Sustainable Development: Developing a Sustainability Literate Society, HEPS, London.

12. Razzouk, R., \& Shute, V. (2012). What is design thinking and why is it important? Review of Educational Research, 82 (3), 330-348.

13. Serve, V. (1957). Teaching mathematics in secondary schools. Mathematical Education, Vol. 1, pp. $22-32$.

14. Steinemann, A. (2003). Implementing sustainable development through problem-solving learning: Pedagogy and practice. Journal of Professional Issues in Engineering Education and Practice, 129, pp. 216-224.

15. The Conference Board. (2006). Are they really ready to work? Employers' Perspectives on the Basic Knowledge and Applied Skills of New Entrants to the $21^{\text {st }}$ Century U.S. Workforce. The Conference Board, 2006. Retrieved March 8, 2019, from https://files.eric.ed.gov/fulltext/ED519465.pdf.

16. World Economic Forum. (2016). The Future of Jobs Employment, Skills and Workforce Strategy for the Fourth Industrial Revolution. Global Challenge Insight Report. Retrieved March 8, 2019, from http:// www3.weforum.org/docs/WEF_Future_of_Jobs.pdf. 
17. World Economic Forum. (2018). The Future of Jobs Report. Insight Report. Retrieved March 12, 2019 , from http://www3.weforum.org/docs/WEF_Future_of_Jobs_2018.pdf.

18. Zeidmane, A., \& Rubina, T. (2018). Problem in development of problem solving skills of studying mathematics at the Latvia University of Life Sciences and Technologies. Proceedings of ICERI2018 Conference, 12-14 November 2018, Seville, Spain, pp. 6181-6188. 